Sign Systems Studies 30.1, 2002

\title{
Beyond self and other: On the neurosemiotic emergence of intersubjectivity
}

\author{
Donald Favareau \\ University of California, Los Angeles \\ 3300 Rolfe Hall, Los Angeles, California, 90095, U.S.A. \\ e-mail: favareau@ucla.edu
}

\begin{abstract}
The explosive growth over the last two decades of neuroscience, cognitive science, and "consciousness studies" as generally conceived, remains as yet unaccompanied by a corresponding development in the establishment of an explicitly semiotic understanding of how the relations of sign exchange at the neuronal level function in the larger network of psychologically accessible sign exchange. This article attempts a preliminary foray into the establishment of just such a neurosemiotic. It takes, as its test case and as its point of departure, recent discoveries from the neurobiological research on viuso-motor transformations and on the widespread cortical phenomena of selectively tuned, single-neuron response to argue for a vision of "intersubjectivity" whereby the ens rationis arising as a function of the neuronal semiosphere may be abstracted, constructed, and shared mutually across agents.
\end{abstract}

\section{Introduction}

Empathy, asserts Hoffmeyer (1996), holds the semiotic antidote to the alienation engendered by the conflation of our organic code duality into narrative agent duality. "Lacan's reflection theory holds the key", he posits, as "the mutual empathy between mother and child provided the protection necessary to cope with the unleashing of the awful isolation inherent in the idea of not" (Hoffmeyer 1996: 133). Such empathy, continues Hoffmeyer, must be felt and not just reasoned into 
existence - "the child must, therefore, be capable of empathizing with 'the other' even before it can talk" (ibid: 132).

Yet at what point in the organization of a semiotic system, it may reasonably be wondered, does the ability to "empathize" take place? If intersubjectivity is, at it appears to be, a prerequisite for language use (and not vice-versa), how many orders of pre-linguistic, biosemiotic interpretation must a creature experience before the dynamic relata of "self" and "other" become robust enough to be brought into relation with each other so as to result in something as seemingly subtle and abstract as intersubjective identification?

Theorists as diverse as Lacan (1977), Bourdieu (1977), Vygotsky (1978) and Tomasello (1999) all attribute the emergence of intersubjective experience in humans (which manifests most commonly at between nine to twelve months of age) as the logical endpoint of an accumulative process of socialized objectification - i.e., the epiphanal and irreversible realization that one, too, is an "object" as well as a "subject" of experience. According to this view, social forces, primarily through language use, finalize irreversibly the invariant self-splitting and objectification of the (presumably) primal "unity" that nature has endowed — the autonomous locus of experience or self.

But does not this picture of the emergence of objectivity (by which agents are then supposed to reason syllogistically to intersubjectivity) leave us bumping up again - even way down here in the primal semiotic - against a fundamental dualism between an incorrigibly dichotic "self" and "other?" Moreover, does not such symbolic and syllogistic reasoning (" $x$ is $y$ to me, therefore I must be $y$ to $x$ ") presuppose both linguaform conceptual reasoning as well the very intersubjectivity it is supposed to engender and explain?

For even allowing for the legitimacy of such socio-centric proposals as Wittgenstein's (1953) assertion that meaning is a function of use or Vygotsky's (1978) notion of personhood arising out of dialogue, it would be impossible to imagine what fundamentally organizing principles would allow such dialogic meaning-building and system-building to occur in the first place, were it not for our particular situatedness "always already" in a pre-linguistic, superordinate meaning-building system of biosemiosis. It is this biological network of sign relations and organization, I will argue, that, at sufficiently complex levels of organization and recursivity, provides 
for the mutual intelligibility of shared experience that is the necessary prerequisite for socialization, language use, and the ability to negotiate and to co-construct meaning to take place.

Thus, given that some common ground of lived, non-verbal experience must bind agents in a mutually intelligible system of relation and signification before anything like entry into a symbolic world (such as may be collaboratively constructed through language and through the communal exploitation of intersubjective identification) can occur - what invariant biological mechanisms and vehicles for sign exchange in human beings, we may ask, constitute the likewise lived embodiment of this experiential "common ground?"

A candidate mechanism that is currently being considered among researchers in the field of the neurobiology of cognition is a class of cells located deep within the brain called "mirror neurons". These neurons - which are located in an area of the brain long associated with both motor control and with language use - instantiate congruent neural firing patterns both during one's own performance of certain highly specific, goal-oriented activities, as well as when one is witnessing passively those same sets of activities being performed by someone else.

This article thus attempts a threefold purpose: (1) to argue for the necessity of applying to such traditionally formulated research findings an explicitly neurosemiotic perspective, (2) to provide a condensed overview of the majority of mirror neuron research extant in the manner that it is presented in the neuroscience literature itself, and (3) by way of illustrating the potential explanatory benefits of applying (1) to (2), to challenge the prevailing notion in the field that the phenomenon of intersubjectivity made possible by the mirror system is the result of rational, deliberative convergence (i.e. agents matching others' external display with their own internal representations and reasoning syllogistically to arrive at a similarity relation).

I will be argue, rather, that the neuroscience data on mirror neuron activity suggests instead that intersubjectivity per se may be the natural, pre-reflexive result of a biosemiotically emergent process and that one's own unitary lived experience of a neurally primitive motor representation that is mutual across agency provides the fundamental iconic grounding upon which both subsequent "self" and "other" representations are hypostatically abstracted. 


\section{On the necessity of establishing the discipline of neurosemiotics}

Commenting on Krampen's proposal to establish the investigation into phyotsemiotics a decade earlier, John Deely, in 1991, termed "surprising...the fact that twenty years elapsed between Sebeok's statement on the dimensions of semiotics [issued in 1968] and the concrete advancement of such a proposal" (Deely 1990: 98). Equally if not more surprising, perhaps, is the fact that a full decade and a half after the publication of Patricia Churchland's (1986) groundbreaking Neurophilosophy, and despite the explosive growth over the last quarter century of neuroscience, cognitive science, and "consciousness studies" generally conceived, an explicitly semiotic approach to neural information processing is as yet nowhere to be seen.

Conspicuous most notably by its absence at a time when current neurobiological research findings are being profitably explored in terms of dynamic systems theory (Kelso 1995; Port, Gelder 1995; Clark 1999), developmental systems theory (Weber, Deacon 2000) and even neurophenomenology (Maturana, Varela 1988; Varela et al. 1991; Gallagher 1996, 2001; Thompson 2001; Zahavi 2001), the establishment of a specifically Peircean neurosemiotic is as long overdue as it is inexplicable, particularly in light of certain otherwise irresolvable paradoxes, mysteries, category errors and confusions that have plagued discussions of the relations of brain states to mental entities since the time of Descartes' infamous cogito.

Accordingly, the use of explicitly semiotic terminology has been and remains assiduously avoided in the practices and explanations of traditional Western science in general — a stark methodological rebuttal to Hoffmeyer's proposal that intelligence lies "not in the sign, but in the interpreting body [... and thus] the exploration of this inner semiosphere ought to be the aim of modern biology" (Hoffmeyer 1996: 125). Such a systematic exploration remains still yet to be undertaken a full 300 years after Locke's call for the formulation of an explicitly semiotic science of representation - "the signs the mind makes use of" (Locke 1959: 461).

Nowhere is this disinclination more evident and, perhaps, more curious, than in mainstream Western neuroscience, wherein the very terms central to its whole agenda - terms such as "signal", "response", "message", "communication", and "command" - are 
understood by its practitioners as mere metaphoric shorthand denoting mechanistic, asemiotic configurations and processes.

Yet as the research we will be reviewing in this article amply illustrates, the explanatory power of traditional reductionist and mechanistic hypotheses "breaks down" in cognitive neuroscientific endeavors earlier and more critically than in, say, classical Newtonian physics - where for everyday, non-technical purposes, the problems of "meaning" and of "knowing" are not central to the stated endeavor.

"Messages" are thus "sent", "received" and "acted upon" in the mechanistic explanations of traditional neuroscience - but the question of "who" (or "what") experiences, systematizes, understands and acts upon the aggregation of these "messages" and their "information" at the level of the integrated organism is either acknowledged as an perpetual mystery ("association cortices" are sometimes invoked as a kind of deus ex machina in hypotheses about human mentation, as if brute congregation alone was somehow sufficient for contemplation - a presumption whose veracity has been disproven repeatedly by five decades of experiments in computer science) - or is summarily dismissed as a fallacy of epiphenomenalism (...and is thus "dismissed", paradoxically, by the "epiphenomenon" it sets out to refute)! What is missing from these otherwise highly successful theories of biological sign transmission, then, is a correspondingly coherent theory of biological sign meaning.

Here, as elsewhere, perhaps the single greatest obstacle to the articulation of such a theory is the persistent and colloquial reduction of the biologically rich category of "sign" to its by no means representative instantiation in human symbolic consciousness as something that is thought to be, in its essence: mentalistic, conceptual, psychological or linguistic. Signs per se, of course, are by necessity none of these things, nor could the very possibility of sign use itself ever be grounded in those relations. Yet because sign relations and sign activities make possible such powerful symbolic relations within those aspects of human beings' lived experience that are mentalistic, conceptual, psychological and linguistic (aspects that are by no means exhaustive of that lived experience), the everyday conflation of sign use with psychological processes precludes any rational explanation of how biological activity can be sign activity prior to its subsequent incorporation in a system of psychologically processed events.

This unfortunate conflation of "sign" with "symbol" exacerbates an already too dichotic understanding of the relationship of mind to 
brain, relegating all sub-psychological processes to biologic mechanism and idealizing all psychological processes to the realm of immateriality. Across such an ontological divide, one cannot reasonably talk about erecting bridges - one can only chalk out the lines of demarcation and become resigned to taking sides.

Such artificial balkanization of experience, however, poses acute problems for the explanations of traditional cognitive neuroscience. Accordingly, an interesting kind of "double-talk" often characterizes its literature. Thus we find that it is hardly heterodox within the discipline to speak of the living activity of neuronal cells as a series of 'signals' (never "signs"), whose individual purpose is 'communication', whose aggregate function is 'information processing', whose distal 'object' is some external or internal stimuli, and whose (proper significate?) 'effect' is, in fact, a multiply mediated response to multiply mediated stimuli. C.S. Peirce, we may assume, would have found this neuronal arrangement evocative.

Unfortunately, the abiding fear of anthropomorphization that attaches to an inadequate understanding of semiotic theory has made the use of explicitly neurosemiotic terminology anathema to the theorists of traditional neuroscience. Such fear is, of course, both counterproductive and unwarranted, for the role of the neurosemiotician — like the role of the cognitive neuroscientist — is not to "anthropomorphize" the individual activity of communally mindless neurons but to understand how the communal activity of individually mindless neurons actively anthropomorphizes, in a very "minded" fashion, $u s$.

To begin examining this process at (or near) its beginning, then, let me first attempt to illustrate how even a cursory acquaintance with the evolution of the basic circuitry which comprises the human brain and nervous system reveals the inherently semiotic nature of the specialized neuronal cell, as that evolution (and those cells) are depicted schematically by one of the pioneers of modern neuroscience in Figure 1. 
A

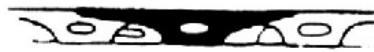

B

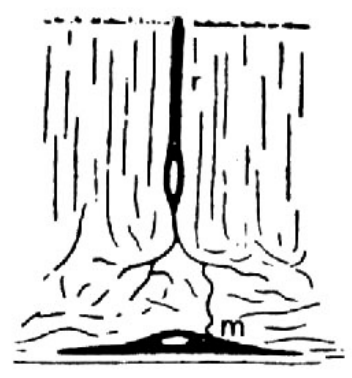

C

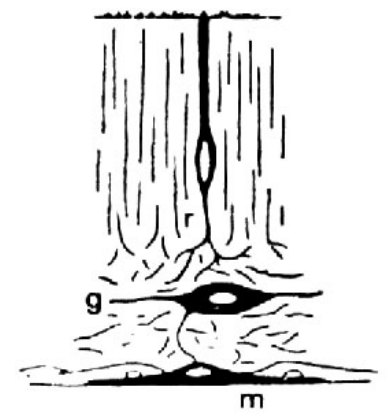

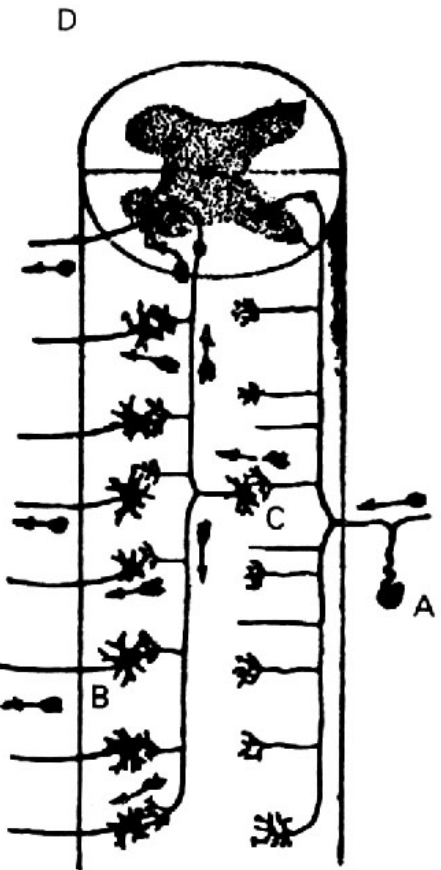

Figure 1. Stages in the semiotic evolution of the nervous system. (A) The motile cell of a primitive sponge responds to surface contact directly with a reciprocal wave of contraction. Feeling, being and doing are unmediated at the level of the organism. (B) The contractile function in the more evolved sea anemone has now been segregated into two specialized elements: ( $r$ ) is a non-contractile sensory receptor cell that is acted upon directly by forces in the environment, but is itself wholly incapable of acting upon that environment and its forces in return. Mediation occurs as stimulation of the external environment's stimulation of (r) triggers the muscle contractile element (m), allowing $(\mathrm{m})$ to act directly upon an environment that it is incapable of directly receiving input from. (C) Further mediation occurs in the sea anemone as a motor neuron $(\mathrm{g})$ is interposed between the non-contractile sensory cell and the non-(externally) sensory muscle element. This motor neuron neither acts upon the external environment nor is acted upon it. Rather, its relation with that environment is wholly mediated by the polar elements of the network of which it is a part. (D) Mediation increases exponentially with the evolution of the vertebrate nervous system. The far majority of communicating cells (the inter-neurons) now connect directly neither to sensory nor to effector cells, but exclusively to other nonexternally interactional, intercommunicating cells. (Illustration adapted from Ramon y Cajal 1911, via Llinas 2001.) 
Mediation, as indicated in Figure 1, is the order of the day for the one hundred billion neurons that (along with the glial cells that support them) constitute the primary physical architecture of exactly one individual human brain. For each one of these 100,000,000,000 living cells receives input from, sends output to, is modified by, and in turn modifies up to 1000 of its neighboring neurons directly and untold millions of its neighbors distally in an ongoing mediation process whose activity must be measured in milliseconds. Thus, it has been pointed out that the number of total possible interactive connections between the neurons of a single human brain far exceeds the number of particles $\left(10^{79}\right)$ thought to comprise the known universe (Edelman, Tononi 2000). Of these interactional possibilities, the ratio between the statistically average 1 million motor neurons, 10 million sensory neurons, and 100 billion interneurons is a mediation-heavy 1:100,000:10.

Yet despite the fact that neuronal cells are specialized into a far greater variety of subspecies than are any other cell type in the animal body, the vast majority of all neurons are comprised of four distinct loci and at least two distinct varieties of incontrovertible signexchange. These are, in the most elementary terms of traditional neuroscience, the electrical input, integrative, and conductile signals by which each individual neuron receives, processes and acts upon digital activation information (at the loci of the dendrites, cell body, and axon, respectively) and the chemical output signal by which each neuron communicates the highly variable results of this information processing to its neighbor through the analog release of neurotransmitters into the synaptic cleft (at the loci of the synaptic terminals).

An extraordinarily simplified - though still, I think, helpful description of the gross mechanics of interneuronal "communication" runs like this: minute changes in the ion gradient diffusing down the living neuron's cell membrane result in a voltage change relative to the outside environment which, upon reaching threshold, produces an electric current which then stimulates the neuron's own synaptic terminals to release chemical neurotransmitters into the synaptic cleft. This, in turn, modifies the ion gradient that will diffuse down the cell membrane of the neurons whose receptors comprise the adjoining half of that synaptic cleft, which results in a voltage change, etc., etc. until at some point in the process the circuit is completed or the threshold state is not reached. 
What is apparent, I hope, even from this one hundred word barebones description, is the critical realization that the processes of neuronal communication - far from conforming to the electrical conduit model proper to computer programming or to electrical engineering - constitute, rather, a paradigm example of the semiotic interrelation known as "code-duality" (Hoffmeyer, Emmeche 1991, Hoffmeyer 1996).

That "code-duality" is, indeed, the organizing principle enabling neuronal communication becomes apparent when one considers that the environmental surround that each neuron is situated in (and with which it interacts with most directly at the site of the synaptic cleft) is a Heraclitian world of ever-changing chemical and molecular interaction and constitution, whose analog representation (what neuroscientists call its "synaptic potential") is constituted by whatever unique configurational state that environment is in at the moment of synaptic (which is presumed to be quantal) release. Conversely, the electric current generated within the neuron and which travels down the axon (referred to, semiotically enough, as an "action potential") as a result of this analog release possesses all the attributes of a purely digital code: it is either wholly present or wholly absent, its amplitude is not variable, it does not decay over time or distance.

Most critically: analog synaptic potentials generate digital action potentials which generate analog synaptic potentials which generate digital action potentials. This ongoing process of semiosis wherein the interactive, consequential interplay between digital and analog cell activity constitutes new signs and new information at every nodal (synaptic) point is, I believe, the starting point upon which the establishment of a discipline of neurosemiotic must be built.

This is very much not the currently popular model of neuronal information processing wherein a presumably unitary "bit" of "information" is literally in the signal of the action potential in the same way that the analog action of a human finger hitting a letter key on a computer keyboard is "in" the micro-pulse of digital electrical current that results ultimately in the appearance of that letter on a computer screen. Such a model, no matter how complex, will never be able to account for the phenomenon of how or where (or, Turing forbid, by "whom") the digital representations of analog experience are ultimately read. For while our computer models already come with meaning-using, sentient beings built into the network of sign- 
exchange (the programmers and the end-users), our brains - under the asemiotic interpretation of neuronal communication and lest one posit the infinite regress of homunculi within homunculi within homunculi - do not.

Thus it is still very much understandably the case that contemporary neuroscience, so incredibly adept at discovering and describing the physio-mechanical aspects of biological sign-exchange, yet lacks even one generally accepted, much less fully explanatory, theory of the very principles by which the emergence of mental representation from neuronal electro-chemical signal transduction is even possible, much less actually accomplished. Neuroscientist Eric Kandel, in the most recent edition his seminal Principles of Neural Science, states both at its outset and at its conclusion that despite the exponentially increasing brain research literature extant, "the neural representation of consciousness and self awareness [... remains] biology's deepest riddle" (Kandel et al. 2000: 16).

"After all," continues Kandel, "to study the relationship between a mental process and specific brain regions, we must be able to identify the components of the mental process that we are attempting to explain" (ibidem). I maintain throughout this article that it is precisely because of contemporary neuroscience's refusal to identify and to include the sign as one of the "components" to be investigated in the emergence of even the most primitive of mental representations, that the most semiotically sedimented and emergent representation of all - that of the "consciousness" of a subjective, internally referential "self" - has been averred to be incorrigible by some philosophers (Horgan 1999, McGinn 1999), and has earned David Chalmers' (1996) definitive appellation as "the hard problem" of consciousness and mind.

For if, as these philosophers have repeatedly asserted, mental representation itself follows laws incommensurable with the laws of physical systems - and if the material objects of the world likewise entertain no efficacy in the causation of mental events - then the problem of how a representational consciousness as such can arise in a physical system (without recourse to a "ghost in the machine") truly is incorrigible.

In Peircean semiotics, however, we find a way out of this impasse with the twin recognition that: (1) 'representation' - as well as the capacity for signification of which representation is but a part - is not 
a process originating from, nor exclusively the domain of, the human mind and that (2) the nature of such 'representation' in a specifically human psychological context does not reduce to a linear, unitary process whereby one presently existing state or thing (such as the rich, subjective experience of "pain") isomorphically "stands for" or corresponds to one other presently existing state or thing (here, the neuronal event "C-fiber stimulation") and so on down the line in the manner of a graphical computer interface until at last one reaches the static, underlying, and finally causal "program code" — but that 'representation' is a fundamentally creative process of interactionally achieved, massively co-constructed mediation across networks of relation $(\mathrm{CP} 4.3)^{1}$ in a complex, open system which ultimately allows the human organism to transcend the brute indexicality of physically present, coextensive and discrete relata and to participate interactively across its own organizational levels - levels which include the intrinsically dynamic elements of neuron, body, sign and world.

The totality of this systemic and incessant sign activity we reify as "mind". An ongoing, dynamic process of sign-exchanging cells embedded in sign-exchanging brains embedded in sign-exchanging bodies embedded in sign-exchanging worlds, the eternal interplay of self-organization and symmetry-breaking that characterizes the moment-to-moment experience of this recursively interactive system constitutes, in a very real sense, the very essences of "knowing" and of "the mind".

Properly seen, body, brain, mind and cell are but levels of the same one endlessly interacting complex system - and if we can view or treat them as distinct, it is more a testament to our own particular species-specific Lebenswelt - or the culture of what Terrence Deacon (1997) calls symbolic reference — whereby we conceptually carve out of the sensory plenum of experience, elements of quality or iconicity (firstness), elements of relation or indexicality (secondness), and elements of synthesis or mediation (thirdness) (CP 1.378). ${ }^{2}$

${ }^{1} \mathrm{CP}$ here refers to Peirce (1931-1935); the numbers correspond to book and paragraph, respectively.

${ }^{2}$ Of the more prominent neuroscientists working in the field today, three in particular - Terrence Deacon (1997), Gerald Edelman (1994, 2000) and Antonio Damasio (1994, 1999) - all explicitly advance the notion that "representation" in the body and in the mind exists as a process as opposed to as an entity or as a collection of neuronal and/or mental particulars. Yet while all three of these scientists acknowledge "representation" as the recursive self-organization of interactions emerging out of, 
In the Peircean conceptualization of brain activity that I will be arguing for, experience dependant and dynamically re-entrant neuronal activity constitutes (to paraphrase Colapietro's analogy with language) "the [indexical] process in which paths are blazed from the object to the sign to the interpretant", whereas consciousness or subjective awareness constitutes "the [symbolic] process in which these paths are traversed" (Colapietro 1989: 19). Under this conception, the very biological semiosis that manifests the multitude of local electro-chemical sign-exchange into the global functional organization of our biological 'selves' finds its explicitly symbolic realization (through its active embodiment in a community of other sign-users) in the conceptual semiosis that manifests itself as our mental 'selves'. This opens up the way towards a dynamic view of the self that is at once iconic, dialogic and triadic.

Such a triadic understanding of the interrelationship between sign, object and interpretant is long overdue in the disciplines devoted to the explication of "human consciousness," both in the often overly idealistic and immateriality-oriented social sciences, as well in the correspondingly reductionist and mechanistic neurosciences of cognition - although it is primarily to the latter that this article will address itself. For against the long-held neural conduit metaphor wherein "information" flows through the circuitry of neurons in much the same way as electricity flows through a computer motherboard (i.e. - in ways in which neither the signal nor the vehicle of its transmission are understood to be themselves interactive participants in the creativity of semiosis) - the massive data collected over the last half century regarding experience-dependent dendrite growth, milieu-responsive axon branching, epigenetic neural self-organization and the ongoing plasticity of synaptic weighting (Kandel et al. 2000) reveals the neural systems of living beings to be precisely what both its outward physical appearance and Sebeok's general theory of semiosis suggests that it would be: neither a carbon-based telephone exchange nor a peptide-bound motherboard for transporting bytes of pre-encoded data for the utility of some distal "user" — but a living,

embedding, and becoming themselves embedded again within other interactions (for Edelman, on the neuronal level; and for Damasio, on the neuroanatomical), only Deacon explicitly recognizes and acknowledges that the very processes whereby representation emerges, is exchanged, and causes other representations to emerge ad infinitum, is essentially an embodiment of the semiotic triadicity of Peirce. 
interactive, massively re-entrant semiotic web, the history of whose organization incorporates its past, is active in the present and extends outwards to the future - "a web of experience woven out of signs and used to catch various objects in our Umwelt for the sake of our survival and flourishing" (Colapietro 1993: 179).

Thus, in its capacity to free us from a purely dyadic ontology of neuronal sign processes consisting only of signals and their carriers, the naturalistic re-introduction of sign-objects, sign-interpretants and sign vehicles into the provenance of neurobiology allows us to transcend the Sausserian dyadism underlying the assumptions of much contemporary neuroscience, whereby mental activity $m$ is "signified" by the presence of neural activity $n$. Such an assumption presumes, of course, that the elements of "signifier" and "signified" are somehow dichotic and discrete and may thus be correlated only "conventionally" or "arbitrarily". This is, obviously, an exceedingly curious position for any study of biological organization to take, and has resulted in a neural nominalism which is far more ubiquitous in the literatures of neuroscience and consciousness than is generally remarked upon.

For until such time as researchers working in the mainstream of the brain sciences understand that neural activity is sign-activity and until such time as theoreticians conversant with the laws and properties of semiotic interaction can contribute to that understanding by dispelling once and for all the ingrained popular misconception that sign activity means mental activity performed by a psychological agent, the serious collaborative dialogue between neuroscience and biosemiotics will remain forever stillborn.

Bearing this last point in mind, though not expecting any overnight paradigm shifts in the fields of either biosemiotics or cognitive neuroscience, I would nonetheless like to attempt something of a preliminary rapprochement between these two fledging disciplines each of which has much to offer the other and each of which, I believe, are investigating much the same phenomena - by applying an explicitly biosemiotic perspective to the findings of traditional neuroscience in an effort to illustrate the mutual enrichment to be had by both fields via the incorporation of such a neurosemiotic. 


\section{Evolutionary and ontogenetic tuning of neurons for selective response}

The fact that both individual neurons and the networks of which they are a part can be selectively "tuned" by evolutionary and by ontogenetic experience (i.e. - that they "take habits" in the Peircean sense) $)^{3}$ was postulated most famously by Donald Hebb in 1949, and has been demonstrated conclusively since by Palm (1982), Grey and Singer (1989), Tsumoto (1992), and Perrett et al. (1982, 1989, 1990), among a multitude of other researchers. ${ }^{4}$

Kobatake and Tanaka's (1994) work on feature recognition at the level of the single neuron is representative of a vast corpus of research into the tendency for certain individual neurons to become exclusively selective or "tuned" to respond to highly specific (and even individual) colors, shapes, movements and particular biological stimuli such as fingers, faces and mouths (Livingstone, Hubel 1987; Perrett, et al. 1989; Hubel 1988; Kandel et al. 2000; Zeki 1993, 1999). A striking example of this neuronal "taking of habits" is illustrated in Figure 2.

Sensorimotor neurons - neurons that mediate both one's perception and one's effecting of the external world - likewise demonstrate high degrees of specificity, as the automaticity with which any conditioned response or sustained deep learning (such as speaking a language, driving an automobile or playing a musical instrument) will immediately attest. In practice, the massively accumulating data on the learning, planning, storage and exponentially recursive "feed-forward/feedback interaction" of motor action sequencing and synchronization "schemas" all but explicitly acknowledges the semiotic components inherent in such deeply interactive patterns of organization.

Gibson's (1950) widely influential notion of "motor affordances", for example, holds that the recognition of the shape of an object and

${ }^{3}$ Such adaptive, spontaneous "tuning" through habituation, of course, is also at the basis of connectionist, or neural networking, models of information processing, selforganization, and learning, many of which attempt to build into mechanical systems the Hebbian postulate of experience-driven cell networking and self-assembly. For an excellent overview and discussion of the shortcomings and potentials of connectionist and other AI/AL research, see Emmeche 1994, and Levy 1992.

${ }^{4}$ See, for example, the Face Recognition Research Homepage at http://www.cs.rug.nl/ peterkr/FACE/face.html for just a partial listing of the hundreds of researchers currently working in this particular sub-field. 
its physical "opportunities for interaction" (its curves, protuberances, angularity, etc.) by a set of selectively tuned sensory neurons is what "triggers" (in the mechanistic terminology acceptable to contemporary neuroscience) a correlated set of selectively tuned motor neurons to produce a corresponding reach and grasp (Gibson 1950, Arbib 2002).
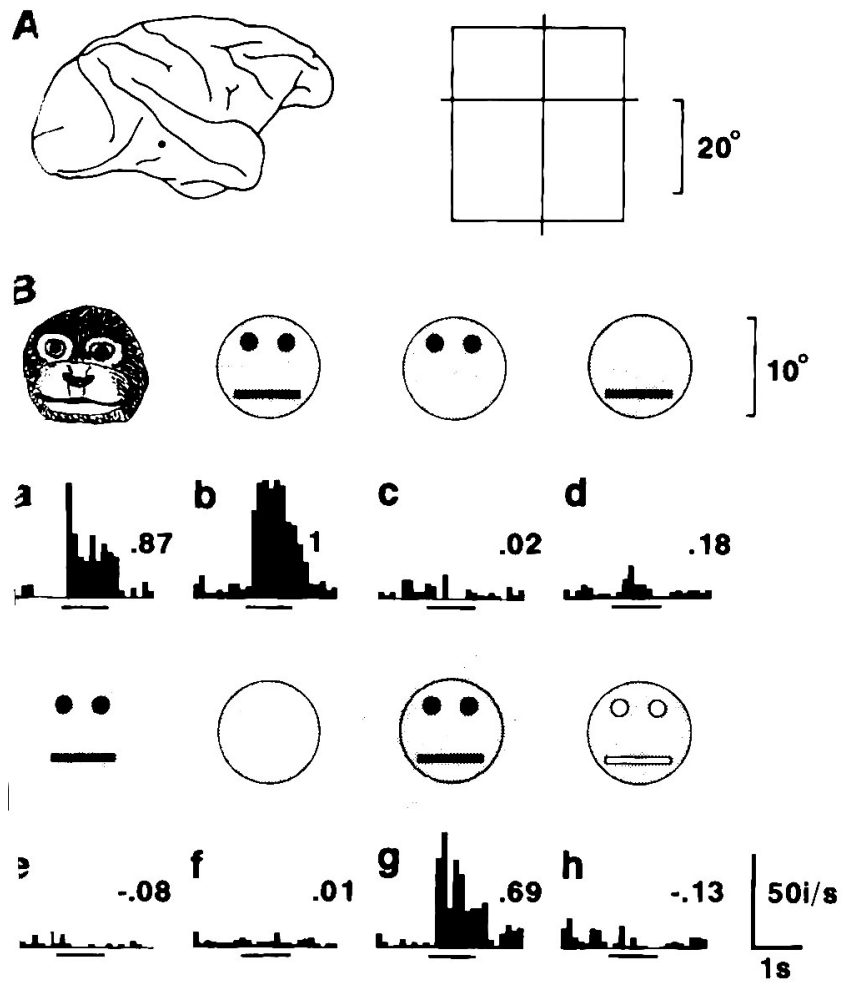

Figure 2. Selectively tuned single neuron response. Recordings made off of a single neuron in the inferior temporal cortex reveal selective responsivity to the critical features of face recognition $(\mathrm{a}, \mathrm{b}, \mathrm{g})$. Incomplete or inverted images (c, d, $\mathrm{e}, \mathrm{f}, \mathrm{h}$ ) failed to activate the neuron to firing threshold. (From Kobatake and Tanaka, 1994.)

Habituation of this type, I wish to argue, has at is basis signification, the process whereby detection of a certain stimulus in a living 
organism comes to elicit a specific response. On the neuronal level, such detection is far from straightforward, as the neurons where such "selective tuning" have been found to occur may be buried deep within multiply embedded networks and pathways which, in turn, themselves have been organized both evolutionarily and through ontogenetic experience via the habituated detection, response and learning of contingent causalities - or, as one might reasonably say, semiotically.

Significantly, recent research in the neurobiology of vision, especially the groundbreaking work of Semir Zeki (1993, 1999) demonstrate conclusively that sensory percepts such as visual images are not so much "received whole" from pre-given incoming photon impulses as they are semiotically and co-constructively "built" across heterogeneous and massively intercommunicating brain areas. Thus we find that sensory signification per se is intimately bound up with motoric processes of bodily and environmental interaction in an ongoing process of semiosis that cuts across the sub-systemic distinctions of brain, body and world. ${ }^{5}$

Semiotically, this organizational network of visual relations is only to be expected, as the evolution of the eye itself rests upon the evolution of a cell which has, over eons of interaction, been tuned to respond selectively to a range of photon configurations in the surrounding environment - a selectivity that ranges on the level of the single neuron from gross (light detection, wavelength perception)

${ }^{5}$ Hoffmeyer (1996) asks how we are to determine where an "individual" starts (or ends!) in an organism that is itself composed of millions of other individual cellular organisms. Clark $(1996,1999)$ in turn, argues that the situating the activity of "mind" exclusively in brain (and not in body and in "world" as well) creates a misleading dichotomy that has been the bane of cognitive science. Hutchins (1995) further unlooses the bounds of inquiry by arguing that cognition per se is distributed across brain, body and world, while Jarvilehto (1998) finally, questions the validity of positing any body-world distinction at all. Thus, the issue of mereology, as Stjernfelt (2000) and Kull (2000) have recently pointed out, is one which any comprehensive semiotic investigation is going to have to ultimately confront.

On the neurobiological level, I will be proposing in a future paper that one felicitous way of dealing with such questions may be via an extension of Hofstadter's (1979) notion of "self-organizing modularity" which finds its neurobiological counterpart in Edelman and Tononi's (2000) notion of neuronal "functional clusters" and their "dynamic core hypothesis" - the neural version, in effect, of Bateson's "difference that makes a difference" - that accounts for the emergence of relatively discrete entities from a plenum of recursive interaction. 
to extremely fine-tuned (individual shapes, movement trajectories, and even highly specific faces, fingers, mouths and hands). Such cells in the aggregate interact with a vast distribution of other selectively specialized cells in the human brain to actively co-construct or "build" a visual image that is not the product of brute mechanical reception and transmission, but of semiosis.

Even more recent findings regarding the neurobiology of visuomotor transformations strongly suggest that at least part of the semiotic and empathic grounding out of which the very experience of intersubjectivity emerges may lie in the activity of a certain class of selectively responsive neuronal cells having both sensory and motor capabilities and that have been evolutionarily tuned to instantiate a congruent neural firing pattern both during one's own execution of highly specific, goal-oriented, object-manipulating activities (grasping, tearing, biting) as well as during one's mere passive observation of those exact same activities being performed by someone else.

The discovery of these so-called "mirror neurons" in humans a little over five years ago may have profound implications not only for our understanding of the sub-personal architectonics of empathy and intersubjectivity, but for a fundamental reappraisal into the continuing viability of any neuroscience of consciousness and mind "asemiotically" conceived. It is thus first to a discussion of the mirror neuron research findings and then to a critical examination of the paradigms in which these findings are currently embedded and interpreted that we now proceed.

\section{A brief research history of mirror neurons}

Confirmation of a mimetically oriented observation/execution system in the brain took place in 1996 during the course of a 15 year-long investigation into the neural substrates for hand and mouth movement in macaque monkeys begun by Giacomo Rizzolatti and his colleagues at the University of Parma, Italy in 1981 (Rizzolatti et al. 1981).

Rizzolatti, Fadiga, Gallese, and Fogassi's seminal 1996 article Premotor cortex and the recognition of motor actions summarized much of the preceding decade's research on the response properties and behavioral modulation of mouth-related neurons in the macaque, emphasizing in particular the discovery of Pellegrino et al. (1992) of a 
subset of rostral ventral premotor (F5) neurons critical to the processes of visuomotor transformation, neurons which Rizzolatti et al. were later to distinguish and to taxonomize as canonical and mirror neurons.

Research by Kurata and Tanji (1986), Petrides and Pandya (1994), and Sakata et al. (1992) offer convergent evidence to Rizzolatti and his colleagues' discovery that ventral premotor area F5 contains organizations of neuronally assembled motor schemas for the execution of highly specific hand movements in its dorsal area and for the execution of highly specific mouth movements in its ventral area. The neurons that comprise these assemblies have both motor (efferent) and sensory (afferent) properties and appear to discharge selectively to visual information received from the anterior intra-parietal sulcus (AIP) rostral to the oculomotor region of the lateral intra-parietal area.

Afferent discharge of the canonical neurons, it was discovered, occurs at the presentation of particular 3-D objects when there is a match between the object's "affordances" (those features of an object relevant to interaction, such as cavity, curve and protrusion) and the type of hand or finger grip encoded for by the neuron. Efferent discharge of canonical neurons occurs during particular goal-related hand movements such as holding, grasping and manipulating objects with either hand or mouth and many of these discharges are specific for particular types of hand prehension, such as precision grip, finger prehension, etc. "Taken together," claim Rizzolatti et al. (1996a: 131), "these data indicate that AIP and F5 form a cortical circuit which transforms visual information on the intrinsic properties of objects into hand movements that allow the animal to interact appropriately with objects".

Rizzolatti et al. (1996a) corollary discovery was that F5 in the macaque also contains a subset of sensory-motor neurons that discharge congruent neural firing patterns both during the actual execution of certain goal-directed hand and mouth movements, as well as during the passive witnessing of those exact same hand and mouth movements whenever they are performed by someone else.

Rizzolatti and his collaborators christened this newly discovered class of neurons mirror neurons and discovered that in order to be triggered, these neurons require an interaction between an agent and an object of a goal-directed action. The simple presentation of objects, or their manipulation in "meaningless" or non-goal directed ways by 
hand (whether witnessed or performed) will not evoke the neuron to discharge (ibidem).

In this now widely-cited series of original experiments, depicted in Figure 3, the macaques were presented with three experimental conditions - first, observation of the experimenter's specific grasping action upon an object followed by their own execution of that same specific action; secondly, observation of the experimenter grasping the same object using a slightly different grasping configuration or using a pliers that duplicates the original grasp upon the object, followed by their own repeated performance of the original object-grasping action; and third, performing the original action in darkness (i.e., - without the accompanying observation of the object or of their own hand). Individual action potentials were recorded off of single neurons using tungsten micro-electrodes through the dura (which was left intact) simultaneous with videotaping of the behavioral events.

As the histograms of single neuron activation demonstrate, activation of the mirror neuron is unique to specific agent-object, goaldirected events (a series of control experiments were performed which ruled out interpretations that this phenomenon was the result of food expectancy, motor preparation for food retrieval, associative training, or reward). In fact, subsequent recordings taken off of a nearby but different F5 mirror neuron in the same monkey, depicted in Figure 4, show that this mirror neuron did not discharge at all to the agentobject interaction configuration that selected for exclusively by its neighboring neuron (c), whether executed or observed. Rather, this mirror neuron discharged only during others' display of - and one's own execution of - counterclockwise but not clockwise rotations of hands that were grasping food (Rizzolatti et al. 1996a).

The discovery of highly selective brain circuitry oriented to goaldirected, agent-object interaction in monkeys - circuitry which on this early level of neuronal organization is activated identically by observation and experience - led to their investigation for a similarly mimetic observation/execution "matching system" in humans. 
A
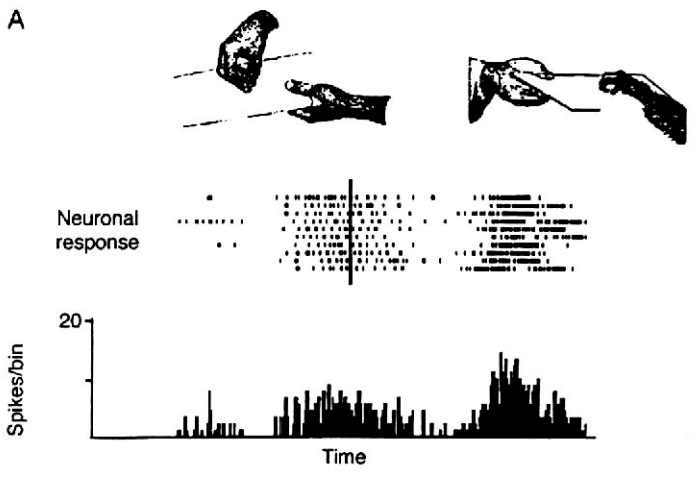

B

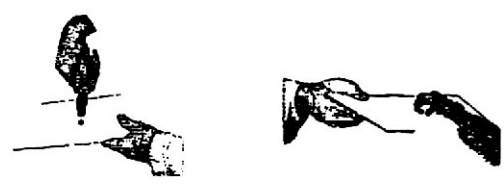

Neuronal response
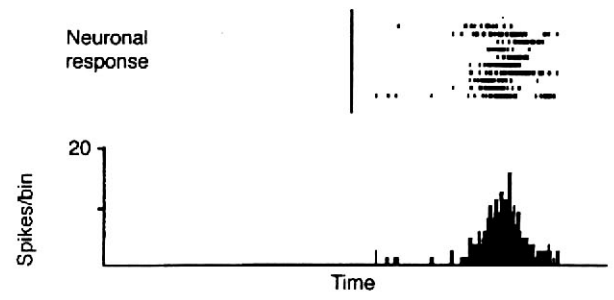

C
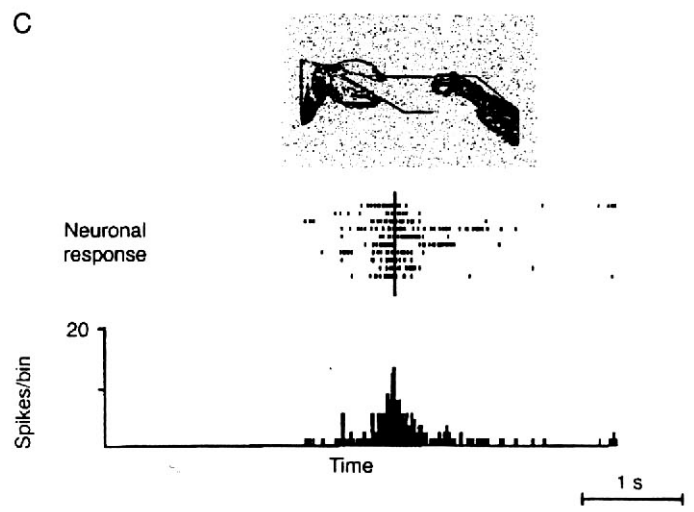

Figure 3. Experimental evidence for the activity of mirror neurons in the macaque. Please see text for details. (Illustration adapted from Rizzolatti et al. 1996a). 
Presenting evidence based on cytoarchitectonics, electrical stimulation studies and sulci embryology, Rizzolatti and Arbib (1998) offer convergent evidence to studies indicating that Area F5 in the macaque monkey brain finds its functional and anatomical homologue in the Broca's area (Brodmann areas 44 and 45, the so-called "language production area") in the human brain (Galaburda, Pandya 1992; Passingham 1993; Bonin 1944).

A

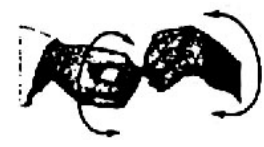

\begin{tabular}{|c|c|c|c|c|}
\hline $\begin{array}{l}\text { Neuronal } \\
\text { response }\end{array}$ & 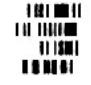 & 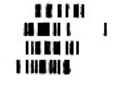 & 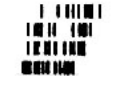 & 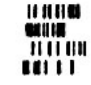 \\
\hline
\end{tabular}

B
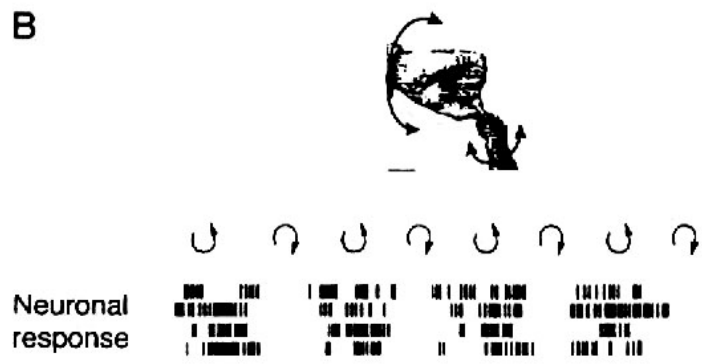

C

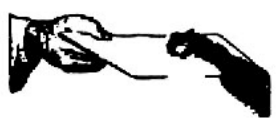

Neuronal

response

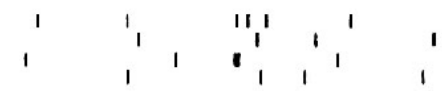

Figure 4. Extreme mirror neuron specificity. Details in text. (Illustration from Rizzolatti et al. 1996a). 
Noting that both monkey and human precentral sulci develop prenatally from the two separate primodia of the superior frontal sulcus (SF) and the inferior frontal sulcus (IF), sharing many homologous functional and anatomical frontal lobe areas as a result. Rizzolatti et al. (1996b) used positron emission tomography (PET) to localize areas where increases in uptake of radioactive fluro-deoxyglucose are most pronounced in the human brain during object observation, grasping observation and grasping execution.

The findings of this study revealed that significant uptake increases (reflecting enhanced neural activity and a measure of increased local work load) during grasping observation does indeed take place in the posterior part of the left inferior frontal gyrus, site of the rostral-most part of the Broca's area. ${ }^{6}$ This finding accords with recent PET studies indicating that - far from being limited to control of the oro-facial and oro-laryngeal musculature necessary for speech production - the human Broca's area also plays a crucial role in motor association (Dronkers et al. 2000) and in the pre-planning and execution of organized sequencing of hand movements as well (Bonda et al. 1994).

Following up on Rizzolatti et al. (1996a) suggestion that the mirror neuron system responds "holistically" to socially embedded actions (and not merely to the discrete elements of movement) in both the monkey and the human brain, Decety et al. (1997) and Grezes et al. (1998) devised an elegant series of experiments wherein human subjects were scanned by positron emission tomography in order to map the differences in brain activity between the observation and the execution of goal-directed, and of similar but non-goal-directed, movements of the human hand.

In all conditions of observation and execution, mirror neurons in the human Broca's area responded just like macaque mirror neurons in F5 - that is, they activated only during goal-directed action-object

${ }^{6}$ It is important to note here that two years earlier, a similar PET experiment was performed during object inspection, movement observation, and motor action "imagining" (Decety et al. 1994). Presenting observers with a computer-generated schematic of a hand - rather than an actual biological hand - this experiment reported some activation in the premotor area during the motor action "imagining" condition, but neither significant premotor nor frontal activation during movement observation. Rizzolatti et al. (1996a: 138) cite this study as supportive of their hypothesis that "non-biological stimuli are ineffective in exciting F5 mirror neurons ... [accounting for why, in the above experiment] the cortical matching system was not activated." 
observations or executions, and did not, significantly, during observation or execution of the object-less, non-goal-directed hand gestures with which the subjects had no semantic understanding or associations.

Similarly, Strafella and Paus (2000) confirmed the discovery of Fadiga et al. (1995) that the simple witnessing of someone else's hand movements increases motor-evoked neuronal activity in the hand muscles of the passive witness, This, in turn, offers yet more convergent evidence to the brain imaging studies of Grafton (1996) and Iacoboni et al. (1999) demonstrating increased activation of the ventral premotor cortex at the Broca's area during passive observation of the hand movements of another.

Finally, the de facto "semiotic" mirror neuron experiments of Iacoboni et al. (1999) at the UCLA Brain Mapping Institute were the first to test for the response of motor and pre-motor mirror neurons to artifactual sign presentation, as well as to the mere observation of motoric hand and finger sequencing.

In these experiments, subjects were required to observe and then to imitate motor actions in response to what were designed to be iconic, indexical, and symbolic cues. In the first condition, iconic stimulation, an animated hand was displayed on a computer screen. The index or the middle finger of the hand was lifted at random, and the subject was instructed to imitate the movement with his or her own right hand. The second condition presented a somewhat more indexical stimulus. A static hand was displayed on the screen, and its index or its middle finger was marked at random with a prominent black " $\mathrm{X}$ ". The instruction to the subject was to lift the corresponding fingers of their own hand in response to the pattern of stationary but marked fingers on the screen. In the third condition, no images of hands at all were presented. Rather a gray rectangle was presented and a solitary symbol — in this case, the letter " $x$ " — appeared on the left or right side of it at random. The instruction was to lift the index finger if a left " $x$ " appeared and the middle finger if a right " $x$ " appeared. Iacoboni and his colleagues found, not surprisingly, that mirror neuron activation was greater during the iconic observation and execution condition than during the indexical or symbolic.

Additionally, Iacoboni et al. (1999) used functional magnetic resonance imaging (fMRI) to pursue the question of how individuals equipped with such automatic observation/execution mirroring mechanisms in the brain, may preserve a sense of self during action obser- 
vation, given the existence of a shared motor-neural pattern which is activated identically by self-execution and by other-observation.

The researchers found, perhaps not surprisingly, that reafferent proprioceptive signals from the parietal operculum - "feedback" between the organism and its ongoing interaction with its object modifies the reception of the input from Broca's area, embedding the signals from the mirror neurons into the larger integration of brain activity of which these signals are but one constituent.

\section{Constructing representema: the sign vehicle of the eye}

Having now reviewed, in the determinedly asemiotic manner of the neuroscience literature itself, some of the major neurobiological research findings of the last half decade, how are we to begin the application of an explicitly Peircean semiotic to the dissipative electrochemical activity of these intercommunicating neurons? More critically, having seen how selective response properties may become, over evolutionary and ontogenetic time, exclusively "associated" with objects and activities that these neurons themselves will never directly experience or "see", is there yet any reason to believe that the organization of this activity constitutes anything other than an electrochemical "bucket brigade", a transfer of streaming brute ion configurations that receive their semantic "meaning", if at all, only at the "input/output" (sensory and motor) "ports" of the self? Conversely, is it reasonable to assert that that the organization of this densely intercommunicative neuronal semiosphere itself partakes in no way of the organization of sign-activity that constitutes 'consciousness' and the "meaning"-making mind?

If we understand semiosis to be an organizing principle of all manner of sign-exchange, then the operational processes enabling signification from receptor cell to interneuron to effector cell and the processes enabling signification across the meta-systems of biological organization (cell, pathway, network, organ, system, body proper) and across levels of awareness (network signification, body signification, mental signification) reveal themselves as systemic parts in a lawful, interactive continuum - a view of mind and body that allows us to transcend the intransigent dualism of a contemporary neuroscience 
"which performs its analysis with an axe, leaving as the ultimate elements, unrelated chunks of being" (CP 7.570).

To understand, then, how the objects of consciousness are related to the sign-exchange activity of the neuronal semiosphere, we need first to understand how the signs of the neuronal semiosphere relate to each other as well as to the objects both of consciousness and of the external world.

We thus begin our explicitly semiotic investigation into the neuronal signification process as virtually all biological investigations must at first begin - that is to say, in media res. The phenomenon under investigation is already always "in full swing" and in our preliminary attempts to fix the points of the process under investigation, it would be fundamentally antithetical to attempt to determine a priori whether and to what extent any given neuronal activity is functioning within its web of dense relations "iconically", "indexically", "symbolically", or — as is most likely — multiply and variously in the manifold of different spatio-temporal networks of which virtually every neuron is a part.

Situated within this web of neuronal interaction, the relata of semiotic interaction - as everywhere, are in no way ontologically "fixed" - icons, indices and symbols do not exist in neuronal semiosphere as entities per se, but only as any given instance of neuronal activity (whether in isolation or as part of a larger, transiently existing or stable configuration) is "taken" to be so through the interpretant (or significate effect) of its particular instantiation.

Thus, activity whose distal object might be some perturbation outside the body is, through the vehicle of the sensory sheet, interpreted as a sign variously (that is: iconically at one point, indexically at another, symbolically at yet another) throughout the resulting cascade of interneuronal activity. For "first of all and most radically, a sign is neither a thing nor an object but the pattern according to which things and objects interweave to make up the fabric of experience" (Deely 1990: 55).

The research on the neurobiology of vision discussed above demonstrates the validity of this neurosemiotic understanding most compellingly: the eye, like the entirety of the sensory sheet, is a signvehicle, the proper significate effect of whose cell by cell activity is not brute "interpretation" in the dyadic sense $(\exists x ; x=y)$, but an entire cascade of top-down and bottom-up, context-dependant and context- 
creating semioses across levels of interpretative and meta-interpretative activity and systems.

"The object seen" (no less than the concept "the self") exists not as a unitary given "presented" to consciousness in the manner of computerized information exchange, but is instead a rich construction of internally biological, externally physical and historically situated, conceptually-mediated elements none of which enjoy a privileged or autonomous causality in structuring or determining the resultant symbol which is then "presented" "seen" or "brought to mind."

Biologically, then, objectification (and the "object world" which the activity of objectification brings forth) is thus a product of the processes of signification and not the other way around. Deely articulates this subtlety most incisively when he reminds us that "an organism does not deal with pure sensations, it deals with objects; and objects are sensations organized according to the nature, wants, needs, and desires of the organism having the sensations" (Deely 1999: 10, emphasis mine).

This object in Peircean terminology is the immediate object — "the Object as the sign itself represents it, and whose Being is thus dependent upon the representation of it in the sign" (CP 4.536) and is the built object of neuronal sign-exchange, providing "objects" (and therefore relata and future grounds) of semiosis for all of the internally sequestered processes of an inherently mediated and cloistered nervous system (processes including, but by no means limited to, symbolic "consciousness," "ideation" and "awareness" at its farthest upper reaches). It is related to its dynamical object - "which is the Reality which by some means contrives to determine the Sign to its Representation" (CP 4.536) - through its situation in the history of an organism's evolutionary and ontogenetic experience.

Brion (1999) captures the essence of the sign's relation to its dynamical object in terms that are deeply resonant with the research findings of evolutionary and developmental neurobiologists:

Because the sign does not stand for the object 'in all respects', then the sign abstracts from the object. 'To abstract from', however, entails selection. Selection entails choice. Choice requires criteria of selection. Criteria of selection necessarily rest on values. That is, the relationship of the sign to the object is value-determined. Thus, the Ground carries out its function as the locus of [signification] — when it is suffused by - a set of values. (Brion 1999: 45) 
Neurobiologically, these "values" — for survival and for thrival operate as the biases and selection pressures driving neuronal organization (Damasio 1994; LeDoux 1996; Deacon 1997; Schumann 1997; Edelman, Tononi 2000). Such organization, in turn, constitutes the primary sign-exchanging network that not so much "links" — as makes semiotically continuous - the external and the internal milieus.

Thus, deep within the interactive tangles of the dense neuronal semiosphere, we can seen how the semiotic object of neuronal activity may be best understood not as some pre-given entity of the outside world miniaturized and made eternal by the video camera of experience, but "that specific item within its context to which all interpretants [or significate effects] of that sign are collaterally related" (Savan 1976: 16). With this notion in mind, and to gain a fuller appreciation of how a semiotic understanding of the mirror neuron research described above may fundamentally challenge our understanding of the nature of intersubjectivity, we must next turn to an examination of certain of the relations that these "built" objects can stand in through reference to their own activity as signs.

\section{Constructing representema: The sign vehicle of the I}

Theorists of the embodied mind (Varela et al. 1991; Allott 1992; McNeill 1992; Hutchins 1995; Armstrong et al. 1995; Clark 1996; Goodwin 1998) remind us that our biology crucially determines our way-of-being in a largely biological world. Our highest-order categories and concepts themselves, claim Lakoff and Johnson (1999), are but conflations of our sensorimotor experience, and because we as human beings are embodied the way we are, there are perceptual and conceptual categories that we must - and others that we may not share with other each other and with other species. It is hardly controversial to assert, then, that perception and conception thus are inextricably and bidirectionally linked.

Moreover, human brains are remarkably unfinished creations at birth (Deacon 1997; Kendel et al. 2000) and among the perceptions which serve as input for our earliest conceptual schemata (and their attendant neuronal self-organization) are the ongoing symbolic interactions — what Bourdieu (1977) calls the habitus — of a reality which both begins as and which then artifactually reifies itself into a 
system of ever more generative signs. "By being included in the process of behavior," writes Vygotsky, "the psychological tool [which is the artifactual vehicle of the sign] alters the entire flow and structure of mental functions" (in Wertsch 1981: 137).

Taking it as axiomatic, then, that cultural transmission and genetic inheritance together orient the individual towards a cognition of negotiated meaning in an ecology of dialogic signs, we can situate the deeply internalized, seemingly ubiquitous concept of "self" as a product of the uppermost symbol level of our "biological inner semiosphere." This is a level which, by definition, includes and yet exceeds (in abstraction and in semiotic freedom) the supporting iconic and indexical levels of the never-ending sign-exchange activity mediating cell, brain, body and world.

Such activity and its resulting properties of causation are nonlinearly interactive across levels of organization — and in their interdependent creation of the symbol known linguistically as the "self," the cultural sign-exchange and the biological sign-exchange exist in intimate symbiosis. "Self" is thus an emergent process of nested iconic, indexical and symbolic localization: it is the carving out of experiential boundaries inherent in the differential causalities of interaction - Bateson's "difference(s) that make a difference" both on the level of cell network architectonics a well as on the level of what Terrence Deacon (1997) refers to as our virtual and symbolic selves.

For just as Zeki's $(1993,1999)$ vision studies indicate that our visual "representations" emerge as complex co-constructions of massively distributed, non-linear processes of interaction which culminate in - but in their constituent parts no way fully constitute - the experienced visual image, so too, does our far more semiotically sedimented sense of "self" emerge from constituent iconic, indexical and symbolic interactions none of which alone contain the full, rich sense of "self" so familiar to our symbolic consciousness. Precisely like a visual representation, this mental representation isn't "given" it is built.

So, too, I will argue that in reference to the mirror neuron data, the richly constructed symbolic concepts of "self" and "other" in their fullest, subjective phenomenological senses require the full hierarchically referential complement of icon, index and symbol for 
their realizations, a complement which may be formalized ontologically as being, relation and law.

We have also seen that in order to determine what "kind" of sign any given neuronal sign activity constitutes, we need to ascertain how that neuronal activity functions as part of its particular representational process. I thus propose that on the neuronal level, as everywhere else, the iconic distinction - not necessarily between a fully semiosic "self" and "other," but simply between any given discrimination being $x$ and not being $x$ - underlies and supports all ascending distinctions, as more increasingly complex hierarchies of organization necessarily rely on preceding ones for their realization and support.

Like Heidegger's Dasein, however, the "what" (as opposed to the "that") of firstness is inaccessible and remains so until such time as it is brought into the system of relations capable of indexicalizing or symbolizing it - at which point, of course, it can no longer be apprehended "in itself" - which is simply to say "in isolation" from the referential system, the system of ongoing semiosis.

Similarly, I wish to argue, the fully seismosic "self" (the self that can know itself as "a self") is likewise inaccessible except through its realization in a vast web of living, semiotic interaction. Because the self is comprised of - and thus cannot exclude - the being, relations and laws of its own situational historicity, of its constitutive relations, and of its physical embodiment, these relations constitute the very vehicles by which experience of "the world" and experience of "the self" must be navigated and thereby known.

Self-representation - the representation of "a self" to a self, even before the further mediation of linguaform awareness - is accomplished through a massively collaborative interaction of signexchange across countless nodes of mediation between cell, brain, body and world. Neuronally, biologically and symbolically, "self" is therefore cumulative, not primal - an achievement, not a given. It is, at its utmost minimum, the mediation or bringing into relation of a sign (iconic self) with another sign ("indexical self") whose operation of semiosis upon it result in what Peirce calls the "mere vicinity" of the egocentric symbol "I" (CP 4.69).

Thus again do we find the 'objects' of the inner semiosphere to be a nexus of collaterally related interpretants, corresponding to what Edelman and Tononi (2000) regard on the neuronal level of organization as 'dynamic functional clusters'. Yet, this does not mean that 
the often maligned "first person view" that results is either an "illusion" or a category mistake. Rather, it is a fact of neuronal, biological and semiotic organization. As the philosopher Thomas Nagel (1986) so eloquently reminds us, there is a particular and singular, nonlinguistic perspective "from here".

What is important to remember, however, is that even our most seamless, immediate and apparently monolithic perspective is, in fact, a built perspective. For, just as on the symbolic level, dialogic relations of action ("x does $y$ ") and interaction (" $\mathrm{x}$ does $\mathrm{y}$ to $\mathrm{z}$ ") characterize the long, post-natal process of human differentiation and individuation, so too on the upwardly organizing neural level, do specifically iconic patterns of neuronal activity (reflexes, fixed action patterns, selectively tuned single neuron response) become repeatedly associated in their co-occurrence with still other iconic patterns of neuronal activity, forming indexical relations which join these icons together into networks of functional relation (Pulvermuller 1999; Edelman, Tononi 2000; Llinas 2001), — the lawfulness of which forms the basis of proprioceptive "self-awareness" and ultimately of the symbolic order.

Neurosemiotically, the ceaseless interaction of these recursive iconic, indexical and symbolic levels of organization provide the substrate for the emergence of a meta-system propensity towards "thirdness" - a propensity which, in our species, finds its apogee in language and in the communal manipulation of publicly negotiated and therefore multiply perspectival signs. It is at this point in its organization that the internally "realized" self — what we now see as the fully dynamic and triadic self (both in its relations with others and in its relations with its own levels of organization) - comes into its own.

The proposal is thus made to consider the "self", both neurobiologically and in its semiotic multiplicity as a being that is simultaneously and interactively iconic, dialogic, and symbolic. I have argued that to equate the "self" as coterminous with biological proprioception, with the first-person perspective, or with a node in a social matrix is to impoverish the conception of "self" by several significant orders - for the self to be a self must be all of these at recursively at once and more. The full "self" as we understand it in our daily lives, is a dynamically determined self at every moment and the relations of which it is inextricably a part (itself, other, language) are likewise 
dynamically and perpetually co-construed. It is therefore as much a product of social interaction as of neurotransmission, for both the interpersonal and the extrapersonal aspects of this self are deeply rooted in a massively non-linear, re-entrant ecology of signs.

This is why, in undertaking the establishment of a discipline of neurosemiotic, it is all the more critical to distinguish the various levels of sign activity, lest we are misled, on the one hand, to positing an eliminativist reductionism that dismisses some of the most vital aspects of our being (such as 'self', 'consciousness' and 'intersubjectivity') as merely epiphenomenal or even downright illusory (a dismissal we may subsequently dismiss as "the illusion illusion" or "the fallacy fallacy") — or, on the other hand, to conflating what is proper only to the milieu of linguistic, socially mediated, symbolic interaction to the brute iconic and indexical significations taking place on the level of the somatic or neuronal cell.

\section{Convergence versus emergence theories of intersubjectivity}

Merleau-Ponty writes in The Prose of the World, "The spectacle begins to furnish itself a spectator who is not I but who is reproduced from me. How is it possible? How can I see something that begins to see?"

It would appear that in their conceptualization of the mirror neuron system as "an observation/execution matching system," the majority of neuroscientists currently examining this phenomenon are indeed conflating iconic, indexical and symbolic levels of semiosis, inadvertently smuggling down onto the neuronal level processes proper to the cultural and the symbolic, or, conversely, reducing what should properly be understood as the emergent phenomenon of "intersubjectivity" down to the computational level of an internal asemiotic algorithm.

To take just two examples: Gallese and Goldman's (1996a) "mirror simulation theory" as well as Rizzolatti and Arbib's (1998) "primitive dialogue theory" advance the notion that "theory of mind" (i.e. - the recognition that the mentation of others is similar to, but distinct from, one's own) is instantiated by the mirror neuron system's matching one's own executed actions with the witnessed actions of 
another. Such "matching," whether in monkey or in human, is supposed to "automatically" result in the cognitive event articulable as: "Agent P's action is similar to mine, therefore Agent P and I are similar."

Leaving aside the homuncular problematic inherent in such asemiotic "matching" of a present and a non-present event (events of "witnessing" and "doing" which are, moreover, experientially disjunct), I maintain that such convergence theories of intersubjectivity assume the very higher-order relational and symbolic capabilities that the existence of the mirror system proposes to explain. Mutuality, under these conceptions, arises after enacted self-with-object interactions and observed other-with-object interactions have been syllogistically and symbolically compared.

For not only reasoning from syllogism, but even the very ability to put one's own experiences into such symbolic relations, I would argue, presupposes higher-order categorization and inferential abilities unlikely to be found at such an early order of neuronal organization. Rather, I will argue that the value of the selectively tuned, single neuron mirroring response to human cognition in general is the provision of a neuronal iconic grounding that is both organizationally prior to - and mutual to - the subsequent system representema of the fully semiosic "self" and "others."

In Figure 5, schematic (A) depicts the reasoning common to the convergence theories regarding the role of the mirror response in enabling intersubjectivity. Here, the physical similarity of neuronal response allows a comparative "matching" to take place whereby agents compare their own inner experiences of witnessing and of performing certain actions, and realize that these two inner experiences are similar. A preliminary computation (not shown) sets up the premises from which a subtractive deduction (in brackets) of phenomenological differences essentializes the relata into a comparison of the actions (A) of self $(\mathrm{S})$ and other $(\mathrm{O})$. This comparison is then syllogistically analyzed (for no other analysis would result in the desired outcome) and as a result of the analysis, the certain degree of similarity between self and other is experienced. 
(A) $\mathbf{O}(\boldsymbol{A})$

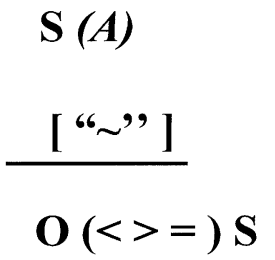

(B)

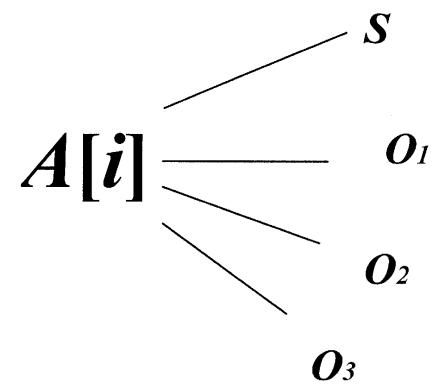

$$
(\mathrm{S}=\text { Self } \quad \mathrm{O}=\text { Other } \quad \mathrm{A}=\text { Action } i=\text { Function })
$$

Figure 5. Convergent versus emergent theories regarding the role of mirror neuron response in enabling intersubjectivity.

The odd combination of computationalism and hidden anthropomorphism apparent in the above description is something that is not at all uncommon in contemporary neuroscientific conjectures regarding the manner in which mental events come to be experienced. ${ }^{7}$ What is

${ }^{7}$ Thus, while present considerations of space and scope force me to limit the discussion of the rest of this paper to a consideration of how the iconic function of the mirror neuron tuned response to specific interaction per se (that is, without consideration as to the identity of the agent of such interaction) may underlie our most symbolic concepts of "self" "empathy" "intersubjectivity" and "other minds", correspondingly 'intractable' problems regarding secondness and thirdness that plague traditional discussions in the literature of cognitive neuroscience will obviously benefit by the application of a Peircean neurosemiotic, as well.

Secondness and relations of indexicality appear to underlie the so-called 'binding problem' (the question, briefly, of why the red is never dissociable from the apple on which it appears), while it is precisely the thirdness of symbols which accounts for the so-called 'hard problem' of consciousness, which is no more than the 'problem' of how a world of iconic and indexical relations ('neuronal activity' in the degenerate information processing sense) could ever result in a world of rich, phenomenological, subjective experience.

Needless to say, I will be addressing these very two complex and demanding issues explicitly in the future. For the purposes of this article, however, it suffices for me to draw the distinction between iconic, self-exhaustive relationships that I believe characterize selectively tuned neuronal response (such as found in mirror neurons) and the kind of "yet computational" view of neuronal activity whereby the activity itself is 
of much more concern to us here is the extraordinarily "weak" picture of "intersubjectivity" that is being offered. "Intersubjectivity" under this conception is not something deeply felt nor experienced, but a logical concept or idea which is calculated and, through the objectivism of deductive reasoning, imaginatively "arrived at." Its inherent efficacy, then, would be as an "abstraction" which one could then choose to act upon or to ignore. This, of course, is in stark contradiction to the experimental results. Mirror neuron response is immediate and involuntary — neither reasoning nor decision making is implicated in the response.

Figure 5 (B) is a schematic depiction which illustrates that an emergent view of the same cause-effect relationship is at once more complex and yet more straightforward. It is straightforward in its insistence that the iconic recognition of "Action A" (or, indeed, of any selective and exclusively "tuned" response) is stable, immediate and primary and does not need to be calculated through a logic of deductive reasoning to be "arrived at" — rather, in its function as an icon, it is the very ground upon which calculations and logical reasoning are enabled to take place, via its provision of a consistently bounded relatum. It is more complex in its insistence of multiply additional layers of sedimentary semiosis before the subsequently emergent relata of "self" and "other" are robust enough to be so distinguished (i.e. - to function in further instances of semiosis as icons of their own).

Following these distinctions to their logical conclusions throws into sharp relief the differences between a neuroscience that is semiotically conceived and one that is not. Let us expand upon these last two points, then, by way of our conclusion, in order to more explicitly illustrate how a neurosemiotic conception of "self and other" "iconicity" and "intersubjectivity" may fundamentally transform our present understanding of phenomena such as mirror neuron activity as well as to open up future neuroscientific research agendas in directions yet precluded by an intransigently asemiotic conception of the relationship between neuronal sign-exchange and the activity of an embodied yet symbolic mind.

not seen as an organic, living system but as lifeless engineering-variety "information" which a larger living system uses to, paradoxically, "know" itself and its world. 


\section{Iconicity in the tuned response}

We have seen how on the neural level, iconicity is "built" through experience both evolutionary and ontogenetically and provides the foundation for the massively re-entrant cascades of still further iconic, indexical and symbolic sign activity that virtually define "mind" in both its most "private" and in its most "distributed" sense — which is to say, in both the subpersonal and in the extra-personal ecology of signs.

Thus, regardless of the surrounding ("upstream" and "downstream") neuronal activity of which it is necessarily a part, we can justifiably establish selectively tuned single neuron response - such as evident in face recognition and in the mirror neuron response - as a ground for iconic activity in the Peircean sense of firstness, that one place predicate or 'raw qualitative experience' which delineates its object as that object (and no other) and which, upon being brought into relation with any other than itself, provides the polarity and brute relata whereby indexical relations (and, ultimately, symbolic relations of thirdness) can then take place. ${ }^{8}$

"Anything whatever", Peirce reminds us, " be it quality, existent, individual or law, is an Icon of anything, in so far as it is like that thing and used as a sign of it" (CP 2.247).

For iconicity, "is not based on some prior ground of physical similarity [i.e. - it is not a matching relation], but in that aspect of the interpretation process that does not differ from some other interpretive process...it is the base on which all other forms of representation are built [and] the bottom of the interpretive hierarchy" (Deacon 1997: 76).

Taborsky (2001) refines this subtle distinction even further when she writes: "This first state of being is not non-relational, but is rather,

8 Note that in our discussion of iconicity, we are not positing the primal experiential iconic relationships of the neuronal system, which must have certainly happened at - and indeed, what must have engendered - the earliest points of its own prehistorically semiotic development, but icons (and indices and symbols) that are functioning as such in the particular instances of semiosis under investigation. Thus, the fact that the iconic response selective to " $x$ and only $x "$ at the site of the "tuned" single neuron may itself be the result of local iconic, indexical and even symbolic relational activity "upstream" (as, in fact, is both concluded by the neurobiological research and predicted by the semiotic of Peirce) in no way changes nor diminishes its function as an icon upon which further semiosis may then legitimately take place. 
the state of being-in-a-relation without the capacity to refer to that relation. It is completely internal and is "present, being such as it is, while utterly ignoring everything else, is positively such as it is (CP 5.44)" (Taborsky 2001: 5). It is precisely this iconic firstness of selectively tuned, mirror neuron response that provides the ground for the subsequent hypostatic abstraction (of "self" and "other" upon the ground of mutually selfless and otherless action qua action iconicity) to take place.

Because mirror neurons distinguish action succinctly but agency not at all, the neurally primitive experience instantiated by either the execution of an action by oneself or the observation of that same action by another functions iconically within the context of the neuronal semiosphere, and is represented congruently in the mirror neuron system as simply the presence of a specific action, A. Iconically, A thus equals A [i] (that is: A is A for all and any agents) prior to the later integration of indexical somatic representations into the still larger symbolic organization of "consciousness" and "self".

Construed thusly, being - that A is and therefore cannot not be is mutual across agency before the ontogenesis of a linguistic and biologically higher-order "self". Differentiation between A[s] and A[o] comes both logically and organizationally later under this hypothesis, for as is almost certainly the case in the many hard-wired reflexes in humans and in other animals - evolution builds in a good many automatic response systems to ensure that a necessary-for-survival strategy is faithfully and unerringly passed on.

Mirror neuron research, rightly construed, demonstrates that not only language, but also actions themselves constitute a "public" domain upon which and out of which the "subject self" is at least partially constructed. Thus, there is no fully cognized "self" to speak of that does not take the actions of others as the fabric from which itself is weaved. Indeed, Pierce reminds us that to maintain that "I am altogether myself and not at all you" constitutes a "metaphysics of wickedness" (CP 7.570). "Others" are in a sense in us and in our actions from the start. 


\section{The neurosemiotic emergence of self from other}

For the majority of theorists working in the field traditionally conceived cognitive neuroscience, however, the notion that the human "subject" is not coterminous with biological individuality and that "neither selves nor neighborselves [are] anything more than mere vicinities"(CP 4.69) may be seen as heresy at best and utter lunacy at worst. Yet from a neurosemiotic standpoint, this assertion is unsensational.

"Immediate feeling is the consciousness of the first; the polar sense is the consciousness of the second; and synthetical consciousness is the consciousness of a third or medium," writes Peirce (CP 1.382). But it is important to distinguish here between the polar sense "something that cannot properly be conceived...for conceive it is to generalize [and therefore] is to miss altogether the hereness and nowness which is its essence" (CP 8.267) - and the fully semiosic relata of the symbolic "self" and "other".

The dialogic and triadic nature of our upwardly organizing self, we have seen, allows our organism to literally construct (realize) a "self" that is made at least partly out of the internalized actions of others actions which are internalized on the neuronal level via mirror system interactions, the nature of which are intersubjective by definition, as part of what mirror neuron pioneer Vittorio Gallese (2001) calls our "subpersonal architecture".

"Self" and "other", in the final analysis, are sign relations that actively construe each other. And thus the argument is made from a neurosemiotic standpoint that the most significant contribution of the mirror neuron system to human cognition is not the "reasoning," dualistic conceptual orientation that representation is mutual between agents - "my representation of $\mathrm{x}$ and your representation of $\mathrm{x}$ occur similarly in both of us, therefore you and I are similar" — but, rather, the inherently neurosemiotic orientation that intersubjectivity mutuality itself - is an iconic, and therefore in some sense a-priori property of representational experience within agents - whereby "my existential and iconic experience of $x$ is mutual to both my symbolically integrated experience of myself and to my symbolically integrated of you".

The sameness of "self" and "other" here is quantitative (the same one) rather than just qualitative (the same as). Empathy and self- 
preservation are thus deeply, inextricably, biologically bound. And in this we might reflect at last that in our capacity as sign-using creatures, we don't primarily reason to "intersubjectivity" — but rather (as the history of our species all too often attests) - "reason" may be one of the strategies by which we move away from it. For at the mirror neuron level of organization, the distinction between seer and doer, action and reaction, identity and alterity is - like the "reflection" one finds oneself presented with in front of a full length mirror - a distinction which is impossible to maintain. Witnessing and performing, "self" and "other", are thus not higher-order behaviors which converge upon the organizationally primitive and biosemiotically prior mirror system - rather, they are but two of the results, products and "proper significate effects" which ultimately emerge from it.

\section{References}

Allott, Robin 1992. The motor theory of language: Origin and function. In: Wind, Jan (ed.), Language Origin: A Multidisciplinary Approach. Amsterdam: Kluwer Academic Publishers, 105-109.

Arbib, Michael A. 2002. The mirror system, imitation and the evolution of language. In: Nehaniv, Chrystopher; Dautenhahn, Kerstin (eds.), Imitation in Animals and Artifacts. Boston: MIT Press. ${ }^{9}$

Armstrong, David T.; Stokoe, William F.; Wilcox, Sherman E. 1995. Gesture and the Nature of Language. New York: Cambridge University Press.

Bateson, Gregory 1972. Steps to an Ecology of Mind. New York: Ballantine Books.

Bonda, E.; Petrides, M.; Frey, S.; Evans, A. 1994. Frontal cortex involvement in organized sequences of hand movements: Evidence from a positron emission tomography study. Society for Neuroscience Abstracts 20: 353.

Bonin, Gerhardt von 1944. Architecture of the precentral motor cortex and some adjacent areas. In: Bucy, Paul Clancy (ed.), The Precentral Motor Cortex. Urbana: University of Illinois Press, 7-82.

Bourdieu, Pierre 1977. Outline of a Theory of Practice. Cambridge: Cambridge University Press.

Brion, Denis J. 1999. The arrow of time: The past and future of law. In: Taborsky 1999: 29-52.

\footnotetext{
${ }^{9}$ Working draft retrieved March 2, 2000 from: http://www-robotics.usc.edu/ $\sim$ billard/arbib/pdf.
} 
Carey, D.; Perrett, D.; Oram, M. 1997. Recognizing, understanding and reproducing action. In: Boller, F.; Grafman, J. (eds.), Handbook of Neuropsychology Amsterdam: Elsevier, 111-129.

Chalmers, David 1996. The Conscious Mind: In Search of a Fundamental Theory. New York: Oxford University Press.

Churchland, Patricia 1986. Neurophilosophy: Towards a Unified Science of the Mind-brain. Cambridge: MIT Press.

Clark, Andy 1996. Being There: Putting Brain, Body and World Together Again. Cambridge, MA: MIT Press.

- 1999. An embodied cognitive science? Trends in Cognitive Science 3(9): 345350.

Colapeitro, Vincent M. 1989. Peirce's Approach to the Self : A Semiotic Perspective on Human Subjectivity. Albany: State University of New York Press.

- 1993. Glossary of Semiotics. New York: Paragon House.

Damasio, Antonio 1994. Descartes' Error: Emotion, Reason and the Human Brain. New York: G. P. Putnam's Sons.

- 1999. The Feeling of What Happens: Body and Emotion in the Making of Consciousness. New York: Harcourt Brace.

Deacon, Terrence 1997. The Symbolic Species: The Co-evolution of Language and the Brain. New York: W. W. Norton.

Decety, J.; Grezes, J.; Costes, N.; Perani, D.; Jeannerod, M.; Procyk, E.; Grassi, F.; Fazio, F. 1997. Brain activity during observation of actions: Influence of action content and subject's strategy. Brain 120: 1763-1777.

Decety, J.; Perani, D.; Jeannerod, M.; Bettinardi, V.; Tadary, B.; Woods, R.; Mazziotta, J.; Fazio, F. 1994. Mapping motor representation with positron emission tomography. Nature 371: 600-602.

Deely, John 1990. Basics of Semiotics. Bloomington: Indiana University Press.

- 1999. Postmodernism and the perfusion of signs. In: Taborsky 1999: 7-13.

Dronkers, Nina F.; Redfern, B.; Knight, R. 2000. The neural architecture of language disorders. In: Gazzaniga, Michael S. (ed.), The New Cognitive Neurosciences. Cambridge: MIT Press, 949-958.

Edelman, Gerald 1994. Bright Air, Brilliant Fire: On the Matter of Mind. New York: Basic Books.

Edelman, Gerald; Tononi, Giulio 2000. A Universe of Consciousness: How Matter Becomes Imagination. New York: Basic Books.

Emmeche, Claus 1994. The Garden in the Machine: The Emerging Science of Artificial Life. Princeton: Princeton University Press.

Fadiga, L.; Fogassi, L.; Pavesi, G.; Rizzolatti, G. 1995. Motor facilitation during action observation: A magnetic stimulation study. Journal of Neurophysiology 73: 2608-2611.

Galaburda, Albert M.; Pandya, D. 1982. Role of architectonics and connections in the study of primate brain evolution. In: Armstrong, Este; Falk, Dean (eds.), Primate Brain Evolution. New York: Plenum, 203-216.

Gallagher, Shaun 2001. The practice of mind: Theory, simulation or interaction? In: Thompson, Evan (ed.) Between Ourselves: Second-Person Issues in the Study of Consciousness. Exeter: Imprint Academic, 83-108. 
Gallese, Vittorio 2001. The shared manifold hypothesis: From mirror neurons to empathy. In: Thompson, Evan (ed.), Between Ourselves: Second-Person Issues in the Study of Consciousness. Exeter: Imprint Academic, 33-50.

Gallese, Vittorio; Goldman, Alvin 1996a. Mirror neurons and the simulation theory of mind reading. Brain 119: 543-609.

Gallese, Vittorio; Fadiga, L.; Fogassi, L.; Rizzolatti, Giacomo 1996b. Action recognition in the premotor cortex. Brain 119: 593-609.

Gentilucci, M.; Fogassi, L.; Luppino, G.; Matelli, M.; Camarda, R.; Rizzolatti, G. 1988. Functional organization of inferior area 6 in the macaque monkey. I. Somatotopy and the control of proximal movements. Experimental Brain Research 71: 475-490.

Gibson, James J. 1950. The Perception of the Visual World. Boston: Houghton Mifflin.

Goodwin, Charles 1998. Action and Embodiment within Situated Human Interaction. Paper presented at the conference for the American Association of Applied Linguistics, Seattle, WA.

Grafton, S.; Arbib, M.; Fadiga, L.; Rizzolatti, G. 1996. Localization of grasp representations in humans by PET: 2. Observation compared with imagination. Experimental Brain Research 112: 103-111.

Gray, C. M.; Singer, W. 1989. Stimulus-specific neuronal oscillations in orientation columns of cat visual cortex. Proceedings of the National Academy of Sciences, USA 86: 1698-1702.

Grezes, J.; Costes, N.; Decety, J. 1998. Top-down effect of strategy on the perception of human biological motion: A PET investigation. Cognitive Neuropsychology 15: 553-582.

Hebb, Donald O. 1949. The Organization of Behavior: A Neuropsychological Theory. New York: Wiley.

Heidegger, Martin 1962. Being and Time. London: SCM Press.

Hoffmeyer, Jesper 1996. Signs of Meaning in the Universe. Bloomington: Indiana University Press.

Hoffmeyer, Jesper; Emmeche, Claus 1991. Code duality and the semiotics of nature. In: Anderson, Myrdene; Merrell, Floyd (eds.), On Semiotic Modeling. New York: Mouton de Gruyter, 177-166.

Horgan, J. 1999. The Undiscovered Mind: How The Human Brain Defies Replication, Medication, and Explanation. New York: Free Press.

Hubel, David 1988. Eye, Brain and Vision. New York: W.H. Freeman.

Hutchins, Edwin 1995. Cognition in the Wild. Cambridge: MIT Press.

Iacoboni, Marco 2000. Mapping human cognition: Thinking, numerical abilities, theory of mind, consciousness. In: Toga, A.; Mazziotta, J. (eds.), Brain mapping: The systems. New York: Academic Press, 523-534.

Iacoboni, Marco; Woods, Roger P.; Brass, Marcel; Bekkering, Harold; Mazziotta, John; Rizzolatti, Giacomo 1999. Cortical mechanisms of human imitation. Science 286(5449): 2526-2528.

Jarvilehto, Timo 1998. The theory of the organism-environment system: I. Description of the theory. Integrative Physiological and Behavioral Science 33: 317-330. 
Jeannerod, Marc 1994. The representing brain: Neural correlates of motor intention and imagery. Behavioral and Brain Sciences 17: 187-245.

Kandel, Eric R.; Schwartz, James H.; Jessell, Thomas M. (eds.) 2000. Principles of Neural Science. $4^{\text {th }}$ ed. New York: McGraw-Hill.

Kelso, S.1995. Dynamic Patterns. Boston: MIT Press.

Kobatake, Eucaly; Tanaka, Keiji. 1994. Neuronal selectivities to complex object features in the ventral visual pathway of the macaque cerebral cortex. Journal of Neurophysiology 71: 856-867.

Kull, Kalevi. 2000. An introduction to phytosemiotics: Semiotic botany and vegetative sign systems. Sign Systems Studies 28: 326-350.

Kurata, K.; Tanji, J. 1986. Premotor cortex neurons in macaques: Activity before distal and proximal forelimb movements. Journal of Neuroscience 6: 403411.

Lakoff, George; Johnson, Mark 1999. Philosophy in the Flesh: The Embodied Mind and its Challenge to Western Thought. New York: Basic Books.

Lacan, Jacques 1977. Ecrits: A Selection. New York: Norton.

LeDoux, Joseph E. 1996. The Emotional Brain: The Mysterious Underpinnings of Emotional Life. New York: Simon \& Schuster.

Levy, Steven 1992. Artificial Life: A Report from the Frontier where Computers Meet Biology. New York: Random House.

Livingstone, Margaret; Hubel, David 1987. Psychophysical evidence for separate for the perception of form, color, movement and depth. Journal of Neuroscience 7: 3416-3468.

Llinas, Rudolfo R. 2001. I of the Vortex. Cambridge: MIT Press.

Locke, John 1959 [1690]. An Essay Concerning Human Understanding. New York: Dover Publications.

McGinn, Colin 1999. The Mysterious Flame: Conscious Minds in a Material World. New York: Basic Books.

McGurk, H.; MacDodd J. 1976. Hearing lips and seeing voices. Nature 264: 746748.

McNeill, David 1992. Hand and Mind: What Gestures Reveal about Thought. Chicago: University of Chicago Press.

Nagel, Thomas 1986. The View From Nowhere. Oxford: Oxford University Press.

Palm, Günther 1982. Neural Assemblies: An Alternative Approach to Artificial Intelligence. Berlin: Springer.

Passingham, R. E. 1993. The Frontal Lobes and Voluntary Action. Oxford: Oxford University Press.

Peirce, Charles Sanders 1931-1935. Collected papers of Charles Sanders Peirce Vols. 1-6, Hartshorne, Charles; Weiss, Paul (eds.); Vols. 7-8, Burks, A. (ed.). Cambridge: Harvard University Press.

Pellegrino, G. di; Fadiga, L.; Fogassi, L.; Gallese, V.; Rizzolatti, G. 1992. Understanding motor events: A neurophysiological study. Experimental Brain Research 91: 176-180.

Perrett, D.; Rolls, E.; Caan, W. 1982. Visual neurons responsive to faces in the monkey temporal cortex. Experimental Brain Research 47: 329-342. 
Perrett, D.; Harries, M.; Mistlin, A.; Chitty, A. 1989. Three stages in the classification of body movements by visual neurons. In: Barlow, H. (ed.), Images and Understanding. Cambridge: Cambridge University Press, 94-107.

Perrett, D.; Mistlin, A.; Harries, M.; Chitty, A. 1990. Understanding the visual appearance and consequence of hand actions. In: Goodale, M. (ed.), Vision and Action: The Control of Grasping. Norwood: Ablex, 163-180.

Petrides, M.; Pandya, D. 1994. Comparative architectonic analysis of the human and the macaque frontal cortex. In: Boller, F.; Grafman, J. (eds.), Handbook of Neuropsychology, vol. 9. Amsterdam: Elsevier, 17-58.

Port, Robert; Gelder, Timothy van (eds.) 1995. Mind as Motion: Dynamics, Behavior and Cognition. Boston: MIT Press, 1-44.

Pulvermuller, Friedmann 1999. Word's in the brain's language. Behavioral and Brain Sciences 22(2): 253-279.

Rizzolatti, Giacomo; Arbib, Michael A. 1998. Language within our grasp. Trends in Neurosciences 21(5): 188-194.

Rizzolatti, Giacomo; Camarda, R.; Fogassi, L.; Gentilucci, M.; Luppino, G.; Matelli, M. 1988. Functional organization of inferior area 6 in the macaque monkey. II. Area F5 and the control of distal movements. Experimental Brain Research 71: 491-507.

Rizzolatti, Giacomo; Fadiga, L.; Gallese, V.; Fogassi L. 1996a. Premotor cortex and the recognition of actions. Cognitive Brain Research 3: 131-141.

Rizzolatti, Giacomo; Fadiga, L.; Matelli, M.; Bettinardi, V.; Perani, D.; Fazio, F. 1996b. Localization of grasp representations in humans by positron emisson tomography: 1. Observation versus execution. Experimental Brain Research 111: 246-252.

Rizzolatti, Giacomo; Gentilucci, M.; Camarda, R.; Gallese, V.; Luppino, L.; Matelli, M.; Fogassi, L. 1990. Neurons related to reaching-grasping arm movements in the rostral part of area 6 (area 6aß). Experimental Brain Research 82: 337-350.

Rizzolatti, Giacomo; Scandolara, C.; Gentilucci, M.; Camarda, R. 1981. Response properties and behavioral modulation of 'mouth' neurons of the postarculate cortex (area 6) in the macaque monkey. Brain Research 225: 421-424.

Sakata, H.; Taira, M.; Mine, S.; Murata, A. 1992. Hand-movement related neurons of the posterior parietal cortex of the monkey: Their role in visual guidance of hand movements. In: Caminiti, R.; Johnson, P.; Burnod, Y. (eds.), Control of Arm Movement in Space. Berlin: Springer-Verlag, 185-198.

Savan, David 1976. An Introduction to C. S. Peirce's Semiotics Part 1. Toronto: Toronto Semiotic Circle.

Schumann, John 1997. The Neurobiology of Affect in Language. Oxford: Blackwell.

Stjernfelt, Frederik 2000. Mereology and semiotics. Sign Systems Studies 28: 7398.

Strafella, Antonio; Paus, Tomas 2000. Modulation of cortical excitability during action observation: A transcranial magnetic stimulation study. Neuroreport 2000 11(10): 2289-2292. 
Summerfield, Q. 1987. Some preliminaries to a comprehensive account of audiovisual speech perception. In: Dodd, Barbara; Campbell, Ruth (eds.), Hearing by eye: The Psychology of Lip-reading. London: Lawrence Erlbaum, 3-51.

Taborsky, Edwina (ed.) 1999. Semiosis Evolution Energy: Towards a Reconceptualization of the Sign. Aachen: Shaker Verlag.

- 2001. The internal and the external semiosic properties of reality. Semiosis, Evolution, Energy, Development [On-line serial], 1(1). ${ }^{10}$

Thompson, Evan 2001. Empathy and consciousness. In: Thompson, Evan (ed.), Between Ourselves: Second-Person Issues in the Study of Consciousness. Exeter: Imprint Academic, 1-32.

Tomasello, Michael 1999. The Cultural Origins of Human Cognition. Cambridge: Harvard University Press.

Tsumoto, T. 1992. Long-term potentiation and long-term depression in the neocortex. Process in Neurobiology 39: 209-228.

Varela, Francisco J.; Thompson, Evan; Rosch, Eleanor 1991. The Embodied Mind: Cognitive Science and Human Experience. Cambridge: MIT Press.

Vygotsky, Lev 1978. Mind in Society: The Development of Higher Psychological Processes. Cambridge: MIT Press.

Weber, Bruce; Deacon, Terrence 2000. Thermodynamic cycles, developmental systems, and emergence. Cybernetics and Human Knowing 7(1): 21-43.

Wertsch, James 1981. The Concept of Activity in Soviet Psychology. Armonk: M. E. Sharpe.

Wittgenstein, Ludwig 1953. Philosophical Investigations. New York: Macmillan.

Zahavi, Dan 1999. Self-Awareness and Alterity: A Phenomenological Investigation. Evanston: Northwestern University Press.

- 2001. Beyond empathy: Phenomenological approaches to intersubjectivity. In: Thompson, Evan (ed.), Between Ourselves: Second-Person Issues in the Study of Consciousness. Exeter: Imprint Academic, 151-168.

Zeki, Semir 1993. A Vision of the Brain. Oxford: Blackwell Scientific Publications.

- 1999. Inner Vision: An Exploration of Art and the Brain. Oxford: Oxford University Press.

\section{По ту сторону своего и чужого: нейросемиотическое проявление интерсубъективности}

Хотя нейробиология, когнитивные науки и "исследования разума" в течении последних двух десятилетий бурно развивались, до сих пор это не сопровождалось таким же развитием в области семиотического понимания исследуемых явлений. До сих пор неизвестно, каким образом

\footnotetext{
${ }^{10}$ Available:

http://www.library.utoronto.ca/see/SEED/Vol1-1/Taborsky-Journal1.html.
} 
знаковые связи на уровне нейронов воздействуют в более широкой сети психологически более доступных знаковых связей. Данная статья пытается очертить возможности подобного подхода именно к нейросемиотике. В качестве пробного материала и точки отправления используются последние открытия в нейробиологии: визульно-моторные переходы и ответные реакции отдельных селективно настроенных нейронов. С этой позиции по поводу “интерсубъективности" утверждается, что ens rationis проявляется как функция нейро-семиосферы, которая может абстрагироваться, конструироваться и взаимно делиться между агентами.

\section{Teispool oma ja võõrast: intersubjektiivsuse neurosemiootiline ilmumine}

Nagu üldteada, pole närviteaduse, kognitiivse teaduse ja "teadvusuuringute" plahvatusliku arenguga kahe viimase kümnendi jooksul siiski tänini kaasnenud samasugust arengut nende valdkondade poolt uuritavate nähtuste semiootilisel mõistmisel. Senini pole teada, kuidas märgiseosed neuronite tasandil saavad toimida psühholoogiliselt ligipääsetavate märgiseoste laiemas võrgustikus. Käesolev artikkel püüab olla esialgseks lähenemiseks just säärasele neurosemiootikale. Oma proovimaterjali ja lähtepunktina kasutame viimaseid avastusi neurobioloogiliste uuringute vallas: visuaal-motoorseid üleminekuid ja üksikneuronite valikuliselt hälestatud vastusreaktsioone, mis on laialtlevinud kortikaalseks nähtuseks. Sellelt lähtekohalt väidetakse "intersubjektiivsuse" kohta, et ens rationis ilmub kui neuraalse semiosfääri funktsioon, mis saab abstraheeruda, konstrueeruda ja toimurite vahel vastastikku jaotuda. 